\title{
Pulmonary lymphohistiocytic reactions temporally related to etanercept therapy
}

\author{
Samuel A Yousem and Sanja Dacic \\ The Department of Pathology, School of Medicine, University of Pittsburgh, Pittsburgh, PA, USA
}

\begin{abstract}
This report details the pulmonary pathologic findings in four patients with rheumatoid arthritis, who developed new onset of pulmonary signs and symptoms with alveolar infiltrates temporally related to the institution of etanercept therapy. Biopsy findings showed an interstitial and air space lymphohistiocytic infiltrate with nonnecrotizing granulomas, in the setting of negative cultures and special stains for microorganisms. The association with etanercept therapy and granulomatous reactions is discussed along with the differential diagnosis.
\end{abstract}

Modern Pathology (2005) 18, 651-655, advance online publication, 5 November 2004; doi:10.1038/modpathol.3800333

Keywords: etanercept; rheumatoid arthritis; granuloma; lung

Rheumatoid arthritis occurs in approximately $1 \%$ of the adult population and is associated with progressive joint destruction and substantial morbidity and mortality. Disease-modifying anti-rheumatic drugs such as methotrexate, prednisone, and nonsteroidal antiinflammatory agents can retard disease progression. However, some patients are unresponsive to these initial therapies and consequently new innovative approaches have been investigated to induce disease remission, based on an understanding that rheumatoid arthritis has, as its core injurious stimulus, an inflammatory reaction that is mediated by various cytokines, especially tumor necrosis factor (TNF). New therapies have focused on modulating the inflammatory response through receptors for TNF (p55 and p75). ${ }^{1-9}$ It is hypothesized that the injection of soluble recombinant human TNF receptors might be useful as a therapy for the disease by binding soluble TNF and abrogating the inflammatory response. Etanercept, a recombinant human TNF receptor $\mathrm{FC}_{\mathrm{C}}$ fusion protein (Enbrel, Immunex Corp., Seattle, Washington, USA) is a dimer consisting of the extracellular portion of two p75 TNF receptors fused to the Fc portion of human IgG1. ${ }^{1,4,5,7}$ Safety studies in normal human volunteers have revealed very few toxic effects with adverse events primarily related to injection site inflammation and localized cutaneous

Correspondence: Dr SA Yousem, MD, Department of PathologyA610, UPMC-Presbyterian, 200 Lothrop Street, Pittsburgh, PA 15213-2582, USA.

E-mail: yousemsa@upmc.edu

Received 7 September 2004; revised and accepted 4 October 2004; published online 5 November 2004 leukocytoclastic vasculitis. ${ }^{10-14}$ Pleuropulmonary manifestations of this therapy are rare with isolated reports of dyspnea, new onset of pulmonary rheumatoid nodulosis, and a systemic sarcoid-like granulomatous reaction. ${ }^{15-18}$ This study details four cases of pulmonary disease associated with the institution of etanercept therapy, with the predominant manifestation being a granulomatous pneumonitis associated with an atypical lymphohistiocytic infiltrate.

\section{Materials and methods}

All cases reported in this study were obtained from the consultation files of one of the authors (SAY). Diagnoses were confirmed on review of the hematoxylin and eosin (H\&E) sections by the two authors. Clinical information was obtained from the patient's records and particularly focused on the relationship of etanercept therapy with the development of pulmonary complications. Immunohistochemistry was performed on two cases using antibodies to CD3, L26, CD5, CD43, CD68, and cyclin D1 (Dako Corp.) using previously described methods. ${ }^{19}$

In situ hybridization studies for Epstein-Barr virus using the EBER probe were also performed on two cases using previously described methods. ${ }^{19}$

\section{Results}

Clinical information pertaining to the four patients in this case report is shown in Table 1. All four were Caucasian women, with three developing rheumatoid arthritis in their fourth decade, and one with 
Table 1 Case summaries: patients with rheumatoid arthritis and etanercept therapy

\begin{tabular}{|c|c|c|c|c|c|c|c|}
\hline Case & Age/race/sex & $S \& S$ (length) & Tobacco use & $\begin{array}{l}\text { Etanercept } \\
\text { dosage/length } \\
\text { of use }\end{array}$ & $\begin{array}{l}\text { Other arthritic } \\
\text { medication }\end{array}$ & Chest radiographs & $\begin{array}{l}\text { Current } \\
\text { pulmonary } \\
\text { status }\end{array}$ \\
\hline 1 & $64 / \mathrm{W} / \mathrm{F}$ & $\begin{array}{l}\text { SOB, } \\
\text { dyspnea, CP } \\
\text { (1 week) }\end{array}$ & - & $\begin{array}{l}25 \mathrm{mg} 2 \times / \mathrm{wk}, \\
3 \text { months }\end{array}$ & Prednisone & $\begin{array}{l}\text { Bilateral alveolar-interstitial } \\
\text { infiltrates }\end{array}$ & $\begin{array}{l}\text { ANED, } \\
2 \text { months }\end{array}$ \\
\hline 2 & $65 / \mathrm{W} / \mathrm{F}$ & $\begin{array}{l}\text { Cough, } \\
\text { dyspnea } \\
\text { (6 weeks) }\end{array}$ & - & $\begin{array}{l}25 \mathrm{mg} 2 \times / \mathrm{wk} \text {, } \\
4 \text { months }\end{array}$ & $\begin{array}{l}\text { Prednisone, } \\
\text { Methotrexate }\end{array}$ & $\begin{array}{l}\text { Lower lobe infiltrates } \\
\text { superimposed on chronic } \\
\text { pulmonary fibrosis }\end{array}$ & $\begin{array}{l}\text { ANED, } \\
10 \text { months }\end{array}$ \\
\hline 3 & $60 / \mathrm{W} / \mathrm{F}$ & $\begin{array}{l}\text { Dyspnea } \\
\text { (1 month) }\end{array}$ & - & $\begin{array}{l}25 \mathrm{mg} 2 \times / \mathrm{wk}, \\
2 \text { months }\end{array}$ & Methotrexate & $\begin{array}{l}\text { New onset reticulonodular } \\
\text { infiltrates with ground glass } \\
\text { change; subpleural scar }\end{array}$ & $\begin{array}{l}\text { ANED, } \\
23 \text { months }\end{array}$ \\
\hline 4 & $40 / \mathrm{W} / \mathrm{F}$ & $\begin{array}{l}\text { Dyspnea, } \\
\text { cough } \\
\text { ( } 3 \text { months) }\end{array}$ & - & $\begin{array}{l}25 \mathrm{mg} 2 \times / \mathrm{wk}, \\
3 \text { months }\end{array}$ & Prednisone & $\begin{array}{l}\text { Upper lobe bronchiectasis with } \\
\text { pulmonary fibrosis }\end{array}$ & $\begin{array}{l}\text { ANED, } \\
23 \text { months }\end{array}$ \\
\hline
\end{tabular}

S\&S—signs and symptoms originating from start of etanercept therapy; SOB—shortness of breath; ANED—alive, no evidence of recurrent acute pulmonary disease.

juvenile rheumatoid arthritis. Two patients were on prednisone supplemented by nonsteroidal antiinflammatory agents, and two were on prednisone and methotrexate. Exacerbations of their arthritis had precipitated the start of etanercept, $25 \mathrm{mg}$ subcutaneous injection twice weekly over the preceding few months.

Two of the four patients had previous diagnoses of 'pulmonary fibrosis' related to rheumatoid arthritis while one was noted to have 'subpleural scarring' on radiographic studies. At the time of lung biopsy, patients had developed new onset of respiratory complaints ranging from 1 week to 3 months from the institution of etanercept therapy, and largely consisted of dyspnea, dry cough, and shortness of breath. Patients \#1 and \#2 were treated with antibiotics for community-acquired pneumonia without response. Chest radiographs showed new alveolar/ground glass infiltrates (four cases) occurring in the setting of underlying chronic inflammatory lung disease in three patients.

All four patients had their etanercept therapy stopped after lung biopsy, and had institution of or dosage augmentation of prednisone. All patients had resolution of their acute/subacute symptoms and pulmonary infiltrates with this clinical intervention.

Three open lung biopsies and one transbronchial biopsy were available for review. The three open biopsies showed similar histologic features. First, there was a background of subpleural scarring, associated with remodeled lung parenchyma, which reflected underlying rheumatoid arthritis associated usual interstitial pneumonia. This was manifested in zones of honeycomb fibrosis, interstitial widening by dense fibrocollagenous tissue and a patchy lymphoplasmacytic infiltrate. Superimposed on this background of interstitial scarring was an acute fibrinous and granulomatous pneumonia, which was patchy and predominantly bronchiolocentric in its distribution (Figure 1). It manifested as

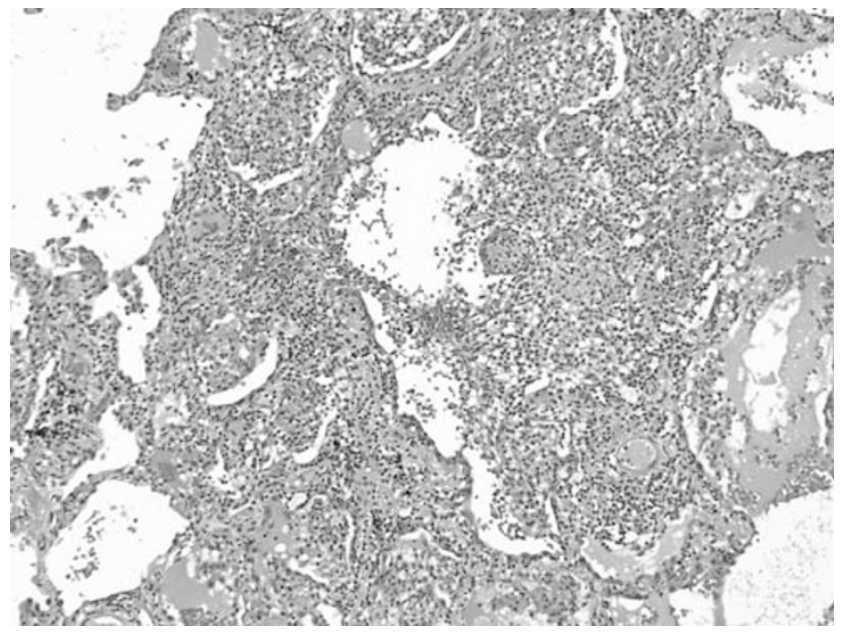

Figure 1 The open lung biopsies showed a patchy interstitial and airspace infiltrate of lymphocytes and histiocytes associated with vague intra-airspace granulomatoid nodules. Blood vessels were cuffed by the mononuclear infiltrate $(\mathrm{H} \& \mathrm{E}, \times 40)$.

airspace filling by macrophages, fibrin, and twisted angulated lymphocytes, which marked as CD3 $+\mathrm{T}$ cells (Figure 2). There was intimate admixture of these $\mathrm{T}$ cells and histiocytes within the air spaces, associated with intra-airspace fibromyxoid connective tissue. A similar mixture of lymphocytes and histiocytes, which formed vague poorly formed granulomas, was noted within the interstitium of the lung at sites of consolidation (Figures 3 and 4). Scattered plasma cells were also noted, as were rare eosinophils. In all three cases, the small arterioles and venules in these regions had a circumferential cuff of atypical lymphocytes and rare plasma cells, which percolated beneath the endothelium and traversed the muscle wall of the vessels, but was unassociated with mural necrosis or fibrinoid change. Rare giant cells were present within the alveolar and interstitial infiltrate but well-formed sarcoid-type granulomas were not identified. 


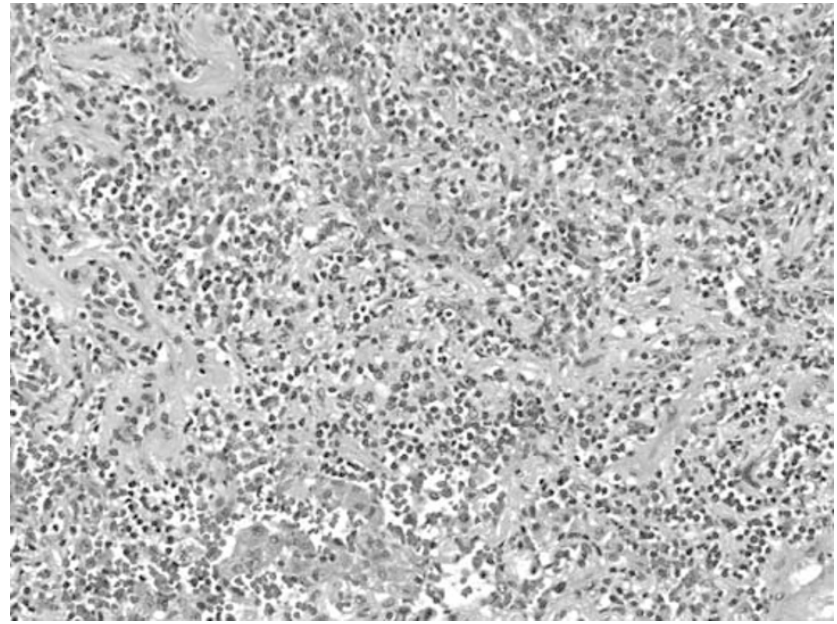

Figure 2 In areas of consolidation, the mixed inflammatory infiltrate was admixed with fibrin (H\&E, $\times 100)$.

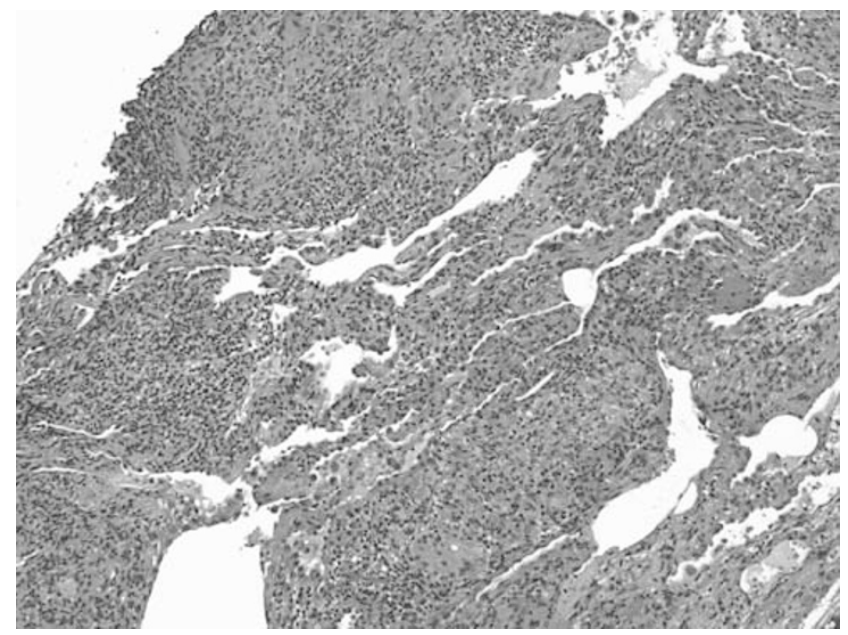

Figure 3 The transbronchial biopsy demonstrated a more prominent nodular interstitial component with more easily recognized epithelioid histiocytes and giant cells. These granulomas were heavily infiltrated by lymphocytes, which infiltrated the subendothelial zones of small blood vessels (H\&E, $\times 100)$.

Immunostains demonstrated that the atypical lymphoid infiltrate was predominantly $\mathrm{T}$ cells with rare or absent B cells. CD68 + macrophages were prominent. No viral inclusions were noted and Gram, Grocott, and acid-fast stains for microorganisms were negative as well as microbial cultures. In situ hybridization studies for Epstein-Barr virus were negative in two cases.

In one transbronchial biopsy, a similar alveolar infiltrate of fibrin, histiocytes, and atypical lymphocytes was noted. In addition, the interstitium contained aggregates of giant cells associated with an intense small lymphocytic, phenotypically T cell, infiltrate. This reaction had a more sarcoidal appearance, with the interstitial granulomas being

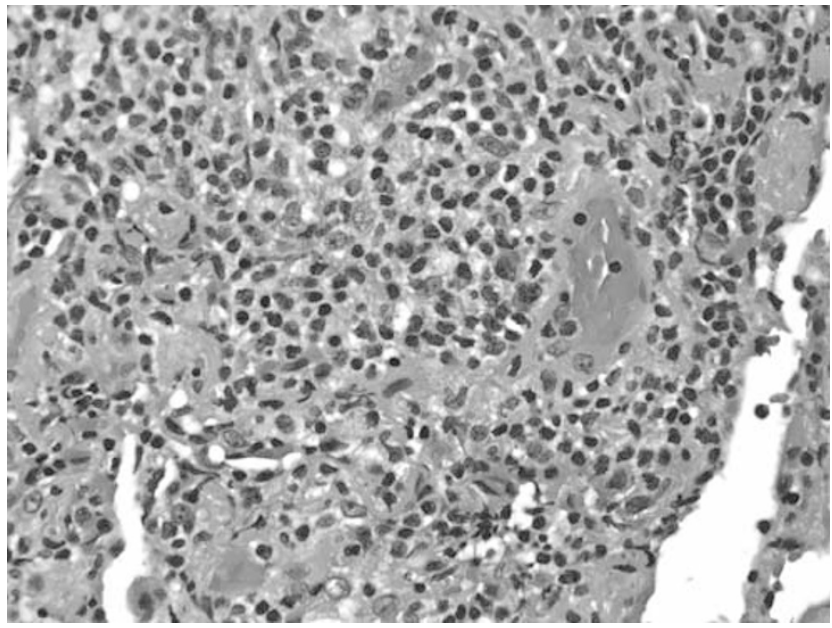

Figure 4 The infiltrate was comprised primarily of angulated small lymphocytes and occasional larger lymphoid cells set in a histiocytic background (H\&E, $\times 160)$.

better defined, but still lacking the circumferential fibrosis and the interstitial fibrosis characteristic of the well-formed tuberculoid granulomas of sarcoidosis. What also seemed unusual about these granulomas was the intense lymphocytic infiltrate within the granulomatous nodules, in contrast to most cases of sarcoidosis where the lymphocytic infiltrate tended to surround the granulomas. Gram, Grocott, and acid-fast stains performed on these transbronchial biopsies were negative.

\section{Discussion}

In addition to its well-recognized synovial and arthritic components, rheumatoid arthritis is associated with pleuropulmonary manifestations in a significant minority of patients. ${ }^{20} \mathrm{~A}$ predisposition to develop usual interstitial pneumonia and nonspecific interstitial pneumonia patterns of lung injury has been well reported in addition to the more classic manifestations of rheumatoid nodules and pleuritis. ${ }^{21}$ Other manifestations of pulmonary disease include eosinophilic pneumonia, organizing pneumonia, and nonspecific cellular interstitial infiltrates. ${ }^{20}$ Rare instances of coexistent sarcoidosis have also been reported. ${ }^{22,23}$ In this study, we report the presence of an unusual granulomatous pneumonia taking place in patients with rheumatoid arthritis temporally associated with the use of etanercept.

Etanercept has been extensively evaluated for adverse reactions in patients with rheumatoid arthritis and its use has recently been expanded to patients with juvenile rheumatoid arthritis, ankylosing spondylitis, psoriatic arthritis, and psoriasis. Such reports have focused largely on site injection reactions, cutaneous changes such as discoid lupus and leukocytoclastic vasculitis, the development of 
malignancies especially malignant lymphoma, emergence of auto-antibodies particularly antiDNA antibodies and cryoglobulins, and an increased risk of infection., ${ }^{70,24,25}$ It is hypothesized that in patients receiving etanercept, immune complex deposits may form, depositing in blood vessels and activating the complement system resulting in vasculitis. ${ }^{26}$ In other cases, it is believed that etanercept induces a change in the macrophage/ T-cell cytokine profile, which may predispose to unique inflammatory reactions, particularly in the skin. ${ }^{15,17,27}$ This may be related, in part, to low levels of TNF permitting an exaggeration of the effects of other inflammatory mediators active in rheumatoid arthritis. These mediators may be chemotactic for a unique set of cellular elements that can result in atypical inflammatory reactions.

Previous reports of etanercept-associated lung injury are scarce. ${ }^{15,17,18}$ Some reports have indicated the new development of rheumatoid nodules in the lung with etanercept therapy, while one report by Peno-Green et $a l^{18}$ focused on new skin and lung lesions, reflecting a systemic non-necrotizing granulomatous process associated with microscopic particulates. The four cases in this report represent acute pulmonary reactions in patients with rheumatoid arthritis, which were temporally related to the institution of etanercept therapy. While we acknowledge that there is an increased incidence of pulmonary infections in etanercepttreated patients, in all cases infection was excluded as the cause of these reactions. The development of an intra-alveolar and interstitial lymphohistiocytic infiltrate associated with fibrin exudation and atypical small lymphocytes is not a pattern usually associated with rheumatoid arthritis. It could represent an unusual reaction to the autoimmune stimuli responsible for nodular rheumatoid lung disease or could conceivably represent an inflammatory reaction to inhaled allergens or infectious agents. Arguing against these latter possibilities would be the negative culture studies and special stains performed on the biopsy specimens, as well as the lack of a defined inhaled allergen. We suspect that this inflammatory reaction represents a peculiar reaction to antibody therapy. It may be tied to an exaggeration of the effects of other inflammatory mediators in the setting of low levels of TNF or could represent a form fruste granulomatous reaction akin to rheumatoid nodules in which the histiocytes do not manifest their full epithelioid and granulomatous potential as a result of this immunotherapy. ${ }^{27}$ Alternatively, the therapy may activate a select population of monocytes. In part, this interpretation could be supported by reports of new rheumatoid nodules developing rather rapidly after the institution of etanercept therapy.

An interesting report by Utz et $a l^{28}$ related the use of etanercept therapy for pulmonary sarcoidosis. ${ }^{28}$ This study from the Mayo Clinic was terminated before completion because of a lack of response or worsening symptoms of patients with stage II/III sarcoidosis with etanercept therapy. The explanation for worsening of a granulomatous disease with etanercept therapy is unclear. In part, this may be tied to TNF alpha promoter polymorphisms in the patient population which may have resulted in stimulation of macrophage response rather than cell death and apoptosis. ${ }^{27}$

The causal association of a drug with pulmonary disease is always difficult to prove. In our cases, there is a temporal association of etanercept therapy with the development of new onset pulmonary symptoms. Our interpretation of drug-induced lung injury, however, is supported by previous studies indicating a granulomatous response to etanercept, as well as the unusual histopathology which is rather unique in our experience, particularly based on our previous studies of rheumatoid arthritisassociated interstitial lung disease. ${ }^{20,29}$ The resolution of acute disease with termination of etanercept and institution of steroids would argue for a drug effect too.

In the differential diagnosis, one needs to consider several potential causes of the pulmonary infiltrates. As noted in previous studies, therapy with etanercept is associated with an increased risk of pulmonary infection..$^{30}$ In our cases, infection was excluded as best as possible by culture studies and special stains. Nonetheless, atypical microorganisms such as Chlamydia and Mycoplasma, which are difficult to culture and identify serologically, could potentially be responsible for the atypical lymphohistiocytic infiltrate. Second, two of our four patients were on chronic methotrexate therapy. Methotrexate has been associated with an interstitial pneumonitis associated with interstitial granulomas. ${ }^{31}$ Arguing against a new onset of methotrexate-induced lung injury is the absence of methotrexate usage in two patients and the longevity of methotrexate therapy in the remaining patients with a recent onset of new alveolar disease timed directly to the institution of etanercept therapy. The histopathology which shows largely airspace disease with prominent airspace histiocytes and lymphocytes as opposed to interstitial granulomas is also atypical in methotrexate injury. Nonetheless, we cannot completely exclude the possibility although we view it as unlikely. Finally, the reaction could represent a form of rheumatoid arthritis-induced lung disease modified by therapy, particularly a form of acute/ subacute decompensation of a chronic autoimmune disorder associated with a UIP-type histopathological pattern.

In summary, these four cases report a peculiar granulomatous pneumonia occurring in the setting of rheumatoid arthritis and etanercept therapy. Although controversial, the histopathologic features, temporal association, and therapeutic response suggest that this reaction is an unusual tissue manifestation of anti-TNF antibody therapy. 


\section{Acknowledgements}

We thank Diana Winters for secretarial assistance and Linda Shab for photographic aid.

\section{References}

1 Geborek P, Crnkic M, Petersson IF, et al. Etanercept, infliximab, and leflunomide in established rheumatoid arthritis: clinical experience using a structured follow up programme in southern Sweden. Ann Rheum Dis 2002;61:793-798.

2 Kremer JM. Rational use of new and existing diseasemodifying agents in rheumatoid arthritis. Ann Int Med 2001;134:695-706.

3 Lipsky PE, van der Heijde DMFM, St Clair EW, et al. Infliximab and methotrexate in the treatment of rheumatoid arthritis. N Engl J Med 2000;343: 1594-1602.

4 Moreland LW, Baumgartner SW, Schiff MH, et al. Treatment of rheumatoid arthritis with a recombinant human tumor necrosis factor receptor (p75)-Fc Fusion protein. N Engl J Med 1997;337:141-147.

5 Moreland LW, Schiff MH, Baumgartner SW, et al. Etanercept therapy in rheumatoid arthritis. Ann Int Med 1999;130:478-486.

6 Moreland LM, Cohen SB, Baumgartner S, et al. Longterm use of etanercept in patients with dmardrefractory rheumatoid arthritis. RA Genetics, ACR Abstract Concurrent Session 2000;S401:1981.

7 Weinberg JM. An overview of infliximab, etanercept, efalizumab, and alefacept as biologic therapy for psoriasis. Clin Ther 2003;25:2487-2505.

8 Weinblatt ME, Keystone EC, Furst DE, et al. Adalimumab, a fully human anti-tumor necrosis factor $\alpha$ monoclonal antibody, for the treatment of rheumatoid arthritis in patients taking concomitant methotrexate. Arthritis Rheum 2003;48:35-45.

9 Weinblatt ME, Kremer JM, Bankhurst AD, et al. A trial of etanercept, a recombinant tumor necrosis factor receptor: Fc fusion protein, in patients with rheumatoid arthritis receiving methotrexate. N Engl J Med 1999;340:253-259.

10 Fleischmann R, Iqbal I, Nandeshwar P, et al. Safety and efficacy of disease-modifying anti-rheumatic agents: focus on the benefits and risks of etanercept. Drug Saf 2002;25:173-197.

11 Flendrie M, Creemer MC, Welsing PM, et al. Survival during treatment with tumour necrosis factor blocking agents in rheumatoid arthritis. Ann Rheum Dis 2003;62(Suppl 2):ii30-ii33.

12 Flendrie M, Creemers MCW, Welsing PMJ, et al. Survival during treatment with tumor necrosis factor blocking agents in rheumatoid arthritis. Ann Rheum Dis 2003;62(Suppl II):ii30-ii33.

13 Soliotis F, Glover M, Jawad AS. Severe skin reaction after leflunomide and etanercept in a patient with rheumatoid arthritis. Ann Rheum Dis 2002;61:850-851.
14 Moreland LW, Cohen SB, Baumgartner SW, et al. Long term safety and efficacy on etanercept in patients with rheumatoid arthritis. J Rheumatol 2001;28:1238-1244.

15 Hubscher O, Re R, Iotti R. Pulmonary rheumatoid nodules in an etanercept-treated patient. Arthritis Rheum 2003;48:559-560.

16 Kekow J, Welte T, Kellner U, et al. Development of rheumatoid nodules during anti-tumor necrosis factor $\alpha$ therapy with etanercept. Arthritis Rheum 2002; 46:843-844.

17 Cunnane G, Warnock M, Fye KH, et al. Accelerated nodulosis and vasculitis following etanercept therapy for rheumatoid arthritis. Arthritis Rheum 2002;47: 445-449.

18 Peno-Green L, Lluberas G, Kingsley T, et al. Lung injury linked to etanercept therapy. CHEST 2002; 122:1858-1860.

19 Nelson BP, Nalesnik MA, Bahler DW, et al. EpsteinBarr virus-negative post-transplant lymphoproliferative disorders: a distinct entity? Am J Surg Pathol 2000;24:375-385.

20 Yousem SA, Colby TV, Carrington CB. Lung biopsy in rheumatoid arthritis. Am Rev Respir Dis 1985; 131:770-777.

21 Nicholson AG, Colby TV, Wells AU. Histopathological approach to patterns of interstitial pneumonia in patients with connective tissue disorders. Sarcoidosis Vase Diffuse Lung Dis 2002;19:10-17.

22 Menard O, Petit N, Gillet P, et al. Association of the histologically proven rheumatoid arthritis with pulmonary sarcoidosis. Eur Respir J 1995;8:472-473.

23 Takashita M, Torisu T, Shinmori Y. Mutilating rheumatoid arthritis associated with sarcoidosis: a case report. Clin Rheumatol 1995;14:576-579.

24 Misery L, Perrot JL, Gentil-Perret A, et al. Dermatological complications of etanercept therapy for rheumatoid arthritis. Br J Dermatol 2002;146:334-335.

25 Nanda S, Bathon JM. Etanercept: a clinical review of current and emerging indications. Expert Opin Pharmacother 2004;5:1175-1186.

26 Mikuls TR, Weaver AL. Lessons learned in the use of tumor necrosis factor-alpha inhibitors in the treatment of rheumatoid arthritis. Curr Rheum Rep 2003; 5:270-277.

27 De Miguel S, Jover JA, Vadillo C, et al. B cell activation in rheumatoid arthritis patients under infliximab treatment. Clin Exp Rheumatol 2003;21:726-732.

28 Utz JP, Limper AH, Kalra S, et al. Etanercept for the treatment of stage II and III progressive pulmonary sarcoidosis. CHEST 2003;124:177-185.

29 Yousem SA, Colby TV, Carrington CB. Follicular bronchitis/bronchiolitis. Hum Pathol 1985;16: 700-706.

30 Fennelly K, Iseman MD. Etanercept or mycobacterium lung injury? CHEST 2003;124:1174-1175.

31 Imokawa S, Colby TV, Leslie KO, et al. Methotrexate pneumonitis: review of the literature and histopathological findings in nine patients. Eur Respir J 2000; 15:373-381. 